\title{
KAJIAN SEPUTAR MODEL PONDOK PESANTREN DAN TINJAUAN JENIS SANTRI PADA PONDOK PESANTREN DARUL QUR'AN AL ANWARIYAH TULEHU
}

\author{
M Sahrawi Saimima, M.Pd.I ${ }^{1}$ Elfridawati Mai Dhuhani, $\mathbf{M} \mathbf{P d}^{2}$ \\ elfridawati@iainambon.ac.id, awisaimima@gmail.com \\ ${ }^{1,2}$ Dosen Prodi MPI FITK IAIN Ambon
}

\begin{abstract}
existence pesantren has been tested by the times, so that until this moment still persists with a variety of dynamics. The most prominent distinctive features that distinguish pesantren with other educational institutions is the education system twenty-four hours, by conditioning the students in a dormitory location divided into rooms or rooms to make it easier to apply. One of them pondok pesantren Darul Qur'an Al Anwariyah in Tulehu District Salahutu Central Maluku District. Pondok pesantren achieved many achievements in the field of religion, namely in Musabaqoh Tilawatil Qur'an (MTQ). Penelitian ini menggunakan metode penelitian kualitatif. In qualitative research there are three data collection techniques used in this study, namely in-depth interviews, participatory observations and documentation studies. For data analysis is carried out in three stages, namely data reduction, data presentation and conclusion drawing. The results of this study showed that Pondok pesantren Darul Qur'an Al Anwariyah Tulehu, can be categorized as pondok pesantren by implementing a modern education system with the type applied a) Integrating the learning system pesantren with formal learning, b) Pondok pesatren this focuses the students to become the students of memorization Al-Qur'an, c) Using the two languages required in daily activities in boarding schools, namely Arabic and English. Then a review of the students in Pondok Pesantren Darul Qur'an Al Anwariyah, based on the analysis conducted in some of the theories above, can be categorized as students in Pondok Pesantren Darul Qur'an Al Anwariyah Tulehu including Santri Mukim, Santri Kalong, Santri Alumnus and Santri Luar.
\end{abstract}

\section{Keywords: Model Pondok Pesantren, Santri Type Review}

Abstrak eksistensi Pesantren sudah teruji oleh zaman, sehingga sampai detik ini masih tetap bertahan dengan berbagai macam dinamikanya. Ciri khas paling menonjol yang membedakan pesantren dengan lembaga pendidikan lainnya adalah sistem pendidikan dua puluh empat jam, dengan mengkondisikan para santri dalam satu lokasi asrama yang dibagi dalam bilik-bilik atau kamar-kamar sehingga mempermudah mengaplikasikannya. Salah satunya pondok pesantren Darul Qur'an Al Anwariyah di Tulehu Kecamatan Salahutu Kabupaten Maluku Tengah. Pondok pesantren ini banyak meraih prestasi dalam bidang keagamaan yakni pada Musabaqoh Tilawatil Qur'an (MTQ). Penelitian ini menggunakan metode penelitian kualitatif. Adapun dalam penelitian kualitatif terdapat tiga teknik pengumpulan data yang digunakan dalam penelitian ini, yaitu wawancara yang mendalam, observasi partisipatif dan studi dokumentasi. Untuk analisis data dilakukan dengan tiga tahap, yaitu reduksi data, penyajian data dan penarikan kesimpulan (verifikasi). Hasil penelitian ini menunjukan Pondok pesantren Darul Qur'an Al Anwariyah Tulehu, dapat dikategorikan sebagai pondok pesantren dengan menerapkan sistem pendidikan yang bersifat moderen dengan tipe yang diterapkan a) Memadukan sistem pembelajaran pesantren dengan pembelajaran formal, b) Pondok pesatren ini memfokuskan para santrinya untuk menjadi para santri penghafal Al-Qur'an, c) Memakai dua bahasa yang diwajibkan dalam aktifitas sehari-hari di pondok pesantren, yakni bahasa Arab dan bahasa Inggris. Kemudian tinjauan tentang para santri di Pondok Pesantren Darul Qur'an Al Anwariyah, berdasarkan analisis yang dilakukan pada beberapa teori di atas, dapat dikategorikan santri pada Pondok Pesantren Darul Qur'an Al Anwariyah Tulehu meliputi Santri Mukim, Santri Kalong, Santri Alumnus dan Santri Luar.

Kata Kunci: Model Pondok Pesantren, Tinjauan Jenis Santri 


\section{PENDAHULUAN}

Kemajuan teknologi dan informasi saat ini membuat pesantren selalu merespon modernitas yang terjadi, namun di sisi lain juga lembaga ini juga tetap tidak meninggalkan kultur aslinya, di sini letak keunikan lembaga pendidikan pesantren dibanding lembaga pendidikan lainnya.

"Di Indonesia, istilah kuttab lebih dikenal sebagai istilah "pondok pesantren" yaitu suatu lembaga pendidikan Islam, yang di dalamnya terdapat seorang Kyai (pendidik) yang mengajar dan mendidik para santri (anak didik). Dengan sarana masjid yang digunakan untuk menyelenggarakan pendidikan tersebut. Serta didukung dengan adanya pondok sebagai tempat tinggal para santri. Ciri-ciri pondok pesantren secara umum diketahui adalah adanya kyai, santri, masjid, dan pondok itu sendiri” (Hasbullah, 2001).

Salah satunya pondok pesantren Darul Qur'an Al Anwariyah di Tulehu Kecamatan Salahutu Kabupaten Maluku Tengah. Pondok pesantren ini banyak meraih prestasi dalam bidang keagamaan yakni pada Musabaqoh Tilawatil Qur'an (MTQ). Di tahun 2019 ini, pada ajang MTQ tingkat Provinsi Maluku yang baru saja dilaksanakan di Kabupaten Buru pada bulan Juni lalu, Pondok Pesantren Darul Qur'an Al Anwariyah Tulehu, mendelegasikan 16 orang peserta terdiri dari 2 orang tenaga pengajar dan 14 orang santri untuk mengikuti berbagai cabang yang diperlombakan. Ke 16 peserta tersebut tersebar di beberapa kabupaten dan kota seperti Kabupatan Kepulauan Aru, Kabupataen Buru Selatan, Kabupaten Seram Bagian Barat, Kabupaten Maluku Tengah dan Kotamadya Ambon. Dari ke 16 delegasi tersebut 13 orang keluar sebagai juara diantaranya juara 1 (2 orang), juara 2 (2 orang), juara 3 (2 orang), juara harapan 1 (4 orang), juara harapan 2 (1 orang) dan juara harapan 3 (2 orang) (Reza Aristo Briliansyah. ww, 2019).

Prestasi-prestasi seperti ini tidak terlepas dari kerja keras dan disiplin yang ditanamkan oleh tenaga pengajar di pondok pesantren kepada para santri mereka. Biasanya untuk mengetahui apakah para santri di pondok pesantren ini berprestasi para santri akan diperbiasakan mengikuti berbagai ajang perlombaan. Salah satunya adalah melalui MTQ, selain itu juga pondok pesantren juga sering mengadakan lomba antar kelas di pondok pesantren. 
Prestasi-prestasi yang diraih oleh para santri di pondok pesantren tersebut, tentu memberikan gambaran kepada peneliti bahwa Pondok Pesantren Darul Qur'an Al Anwariyah merupakan model pondok pesantren yang menerapkan sistem pembelajaran yang efektif.

\section{METODE PENELITIAN}

Pendekatan metode yang digunakan dalam penelitian ini adalah kualitatif. Adapun dalam penelitian kualitatif terdapat tiga teknik pengumpulan data yang digunakan dalam penelitian ini, yaitu wawancara yang mendalam, observasi partisipatif dan studi dokumentasi. Untuk analisis data dilakukan dengan tiga tahap, yaitu reduksi data, penyajian data dan penarikan kesimpulan (verifikasi).

\section{TINJAUAN PUSTAKA}

\section{Pondok Pesantren}

Pondok Pesantren sebagai lembaga Pendidikan Islam di Indonesia memiliki perbedaan dengan yang lainnya. Baik dari segi aspek pendidikan ataupun dari aspek sistem pendidikan yang diterapkan. Ada beberapa ciri atau karakter yang harus dimiliki oleh pesantren sebagai lembaga pendidikan dan lembaga sosial yang secara informal terlibat dalam pengembangan masyarakat. Terdapat lima unsur yang tidak bisa dipisahkan dari pondok pesantren yakni adanya Masjid, Pondok, Pengajaran pada kitab-kitab Islam klasik, Santri dan sosok Kiyai (M.Nur Hasan, 2016).

Banyak diantara para ahli yang memberikan pengertian tentang pesantren dengan pengertian yang berbeda-beda. Pengertian terkait pesantren yang dipersepsikan berkaitan dengan darimana ia memandang sebuah pesantren dengan segala aplikasinya.

Zamakhasyari Dhofier dalam (Dhuhani, 2018) mendefinisikan kata 'pondok' berasal dari pengertian asrama-asrama yang menaungi para santri, atau yang disebut pondok, tempat tinggal yang dibuat dari bambu atau juga berasal dari kata Arab funduq dengan memiliki arti hotel atau asrama.

\section{Model Pondok Pesantren}

Pesantren merupakan asrama pelajar Islam dimana para santri belajar di sekolah-sekolah atau di perguruan-perguruan tinggi di luarnya. Pendidikan agama di pesantren model ini diberikan di luar jam-jam sekolah sehingga bisa 
diikuti oleh semua santrinya. Diperkirakan pesantren jenis inilah yang terbanyak jumlahnya (Kompri, 2018).

Bahri Ghozali, mengemukakan beberapa tipe pondok pesantren terbagi kedalam tiga tipe;

a. Pondok Pesantren Tradisional

Pondok pesantren tradisional yaitu pondok yang dalam perkembangannya pesantren tersebut menyelenggarakan pelajaran dengan pendekatan tradisional. Pembelajarannya ilmu-ilmu agama Islam dilakukan secara individual atau kelompok dengan konsentrasi dengan kitab-kitab klasik berbahasa Arab.

b. Pondok Pesantren Modern

Pondok pesantren moderen adalah pondok pesantren yang menyelenggarakan kegiatan pendidikan dengan pendekatan modern melalui suatu pendidikan formal, baik madrasah ataupun sekolah, tetapi dengan menggunakan cara klasikal.

c. Pondok Pesantren Komprehensif

Pondok pesantren komprehensif adalah pondok pesantren yang sistem pendidikan dan pengajarannya gabungan antara yang tradisional dan yang moderen. Artinya didalamnya ditetapkan pendidikan dan pengajarannya kitab kuning dengan metode sorogan, bandongan, wetonan, namun secara regular sistem persekolahan terus dikembangkan (M.Bahri Ghozali, 2002).

Pondok Pesantren dengan keanekaragamannya termasuk lembaga atau organisasi pendidikan yang unik. Antara lain karena di pondok pesantren terdapat figur Kiyai yang memiliki peranan dan kewenangan yang besar didalamnya. Dalam tahap perkembangannya, Zamarkhasyi Dhofier dalam Kompri membagi pesantren ke dalam dua bagian:

a. Pesantren Salaf, adalah lembaga pesantren yang mempertahankan pengajaran kitab-kitab klasik sebagai inti pendidikan. Adapun sistem madrasah ditetapkan hanya untuk memudahkan sistem yang dipakai dalam lembaga-lembaga pengajian bentuk lama, tanpa mengenalkan pengajaran pengetahuan umum. 
b. Pesantren Khalaf, adalah lembaga pesantren yang memasukan pelajaran umum dalam kurikulum madrasah yang dikembangkan, atau pesantren yang menyelenggarakan tipe-tipe sekolah umum seperti SMP, SMA dan bahkan perguruan tinggi dalam lingkungannya (Kompri, 2018).

Kedua tipe yang dikemukakan tersebut menjadikan pesantren mendapatkan posisi teristimewa pada masyarakat untuk menyekolahkan anak mereka ke pesantren, sebab Pondok Pesantren telah menjadi institusi yang dekat dengan masyarakat, menjadi agen pemberdayaan, sekaligus mampu memaknai permasalahan lingkungan dari jarak yang sangat dekat. Pesantren selalu menempatkan prioritas pada masyarakat sebagai sebuah ikatan tradisional. Potensi ini menjadi kekuatan pesantren sejak awal. Dimana tumbuh kembangnya justru berawal dan selalu berada di masyarakat (Ismail Suardi Wekke, 2017).

\section{Santri}

Menurut Abu Hamid dalam Yakub istilah santri berasal dari kata shastra (i) dari bahasa Tamil yang berarti seorang ahli buku suci (Hindu). Dalam dunia pesantren istilah santri adalah peserta didik di pesantren yang biasanya tinggal di asrama atau pondok (H.M Yacub, 1993). Menurut para ahli santri dapat dikelompokkan beberapa bagian yaitu:

\section{a. Santri Mukim}

Mereka peserta didik yang berasal dari daerah yang jauh dan menetap dalam kelompok pesantren. Santri mukim yang paling lama tinggal di pesantren tersebut biasanya merupakan satu kelompok tersendiri yang memegang tanggung jawab mengurusi kepentingan pesantren sehari-hari, mereka juga memikul tanggung jawab mengajar santri-santri muda tentang kitab-kitab dasar dan menengah (H.M Yacub, 1993).

\section{b. Santri Kalong}

Peserta didik yang berasal dari daerah sekeliling pesantren, yang biasanya tidak menetap dalam pesantren. Untuk mengikuti pelajaran di pesantren, mereka bolak-balik dari rumahnya sendiri. Biasanya perbedaan antara pesantren besar dan pesantren kecil dapat dilihat dari komposisi santri kalong (Zamakhsyari Dhofir, 1985). 
Sedangkan Arifin dan Sunyoto dalam Imron Arifin menemukan ada dua (2) bentuk kelompok santri yang lain yaitu:

\section{a. Santri Alumnus}

Adalah para santri yang sudah tidak dapat aktif dalam kegiatan rutin pesantren, tetapi mereka masih sering datang pada acara-acara tertentu yang diadakan pesantren. Mereka masih memiliki komitmen hubungan dengan pesantren, terutama terhadap kyai pesantren.

\section{b. Santri Luar}

Menurut Arifin dan Suyoto dalam Imran Arifin bahwa santri luar adalah santri yang tidak terdaftar secara resmi di pesantren sebagaimana santri mukim dan santri kalong, tetapi mereka memiliki hubungan batin yang kuat dan dekat dengan Kyai, sewaktu-waktu mereka mengikuti pengajian-pengajian agama yang diberikan oleh Kyai, dan memberikan sumbangan parsitipatif yang tinggi apabila pesantren membutuhkan sesuatu (Imron Arifin, 1993).

HASIL

Berdasarkan hasil penilitian yang dilakukan, pondok pesantren Darul Qur'an Al Anwariyah Tulehu, dapat dikategorikan sebagai pondok pesantren dengan menerapkan sistem pendidikan yang bersifat moderen. Pernyataan ini bukan tanpa alasan, melainkan dengan menganalisis berbagai konteks Pondok Pesantren Darul Qur'an Al Anwariyah Tulehu itu sendiri yang memadukan sistem pembelajaran pesantren dengan proses pendidikan sekolah formal di dalamnya, kemudian menggunakan dua bahasa yang diwajibkan dalam aktifitas sehari-hari di pondok pesantren, yakni bahasa Arab dan bahasa Inggris.

Selain itu santri pada Pondok Pesantren Darul Qur'an Al Anwariyah Tulehi meliputi Santri Mukim, Santri Kalong, Santri Alumnus dan Santri Luar. Santri mukim adalah santri santri yang tempat tinggalnya berjauhan dengan lokasi pondok pesantren, tetapi ada juga sebagian santri yang tempat tinggal dekat dengan pondok pesantren memilih untuk menjadi santri mukim. Adapun dalam kategori santri mukim dimulai santri pada jenjang pendidikan kelas 4 SD sampai dengan lulus SMP. Santri kalong adalah santri yang tempat tinggal mereka berada dekat di sekitar pondok pesantren, santri kalong dapat dikategorikan pada jenjang pendidikan kelas 1 sampai kelas 3 SD. kelas 1 sampai 3 SD 
masih dibolehkan untuk pulang ke rumah mereka. Santri alumnus adalah santri yang telah lulus dalam kegiatan rutin di pondok pesantren. Sebagian para santri yang telah lulus dalam menempuh pendidikannya memiliki andil besar untuk kembali mengabdikan dirinya sebagai tenaga pengajar di pondok pesantrennya. Santri luar adalah santri yang secara resmi tidak terdaftar di pesantren seperti santri mukim dan santri kalong akan tetapi keberadaan mereka memiliki hubungan yang baik dengan pondok pesantren. Adapun yang termasuk santri luar di Pondok Pesantren Darul Qur'an Al Anwariyah Tulehu adalah para santri di TPQ Nurul Latif dan juga majelis pemuda (masyarakat tulehu yang tinggal di sekitar pondok pesantren).

\section{PEMBAHASAN}

\section{Perkembangan Pondok Pesantren}

Di dalam Peraturan Pemerintah Republik Indonesia Nomor 55 Tahun 2007 Tentang Pendidikan Agama dan Pendidikan Keagamaan pondok pesantren memiliki kewenangan diantaranya;

a. Pesantren menyelenggarakan pendidikan dengan tujuan menanamkan keimanan dan ketakwaan kepada Allah SWT, akhlak mulia, serta tradisi pesantren untuk mengembangkan kemampuan, pengetahuan, dan keterampilan peserta didik untuk menjadi ahli ilmu agama Islam (mutafaqqih fiddin) dan/atau menjadi muslim yang memiliki keterampilan/keahlian untuk membangun kehidupan yang Islami di masyarakat.

b. Pesantren menyelenggarakan pendidikan diniyah atau secara terpadu dengan jenis pendidikan lainnya pada jenjang pendidikan anak usia dini, pendidikan dasar, menengah, dan/atau pendidikan tinggi.

c. Peserta didik dan/atau pendidik di pesantren yang diakui keahliannya di bidang ilmu agama tetapi tidak memiliki ijazah pendidikan formal dapat menjadi pendidik mata pelajaran/kuliah pendidikan agama di semua jalur, jenjang, dan jenis pendidikan yang memerlukan, setelah menempuh uji kompetensi sesuai ketentuan Peraturan Perundang-undangan.

Sejak berdirinya pondok pesantren Darul Qur'an Al Anwariyah Tulehu di tahun 2001, sampai saat ini pondok pesantren Darul Qur'an Al Anwariyah telah mengalami perkembangan yang cukup baik melalui presetasi-prestasi yang 
diraih oleh para santrinya melalui berbagai kegiatan keagmaan. Kegiatan seperti Porseni, Musabbaqoh Tilawatil Qur'an (MTQ) setiap kegiatan tersebut dilaksanakan, para santri dari pondok pesantren Darul Qur'an Al-Anwariyah turut andil dan berpartisipasi sebagai peserta dalam mengikuti kegiatan tersebut. Hal ini juga tidak terlepas dari fokus pesantren ini yang mendidik para santrinya untuk menjadi penghafal AI-Qur'an.

Pondok pesantren Darul Qur'an Al Anwariyah menyelenggarakan pendidikan diniyah secara terpadu dengan jenis pendidikan pada jenjang pendidikan dasar dan menengah. Adapun sistem pendidikan yang diselenggarakan di pondok pesantren tersebut adalah memadukan antara sistem pendidikan pesantren dan pendidikan formal. Kemudian fokus pesantren ini juga adalah mendidik para santrinya untuk menjadi penghafal AI-Qur'an.

\section{Model pondok pesantren Darul Qur'an Al Anwariyah Tulehu}

Pondok pesantren Darul Qur'an Al Anwariyah Tulehu, dapat dikategorikan sebagai pondok pesantren dengan menerapkan sistem pendidikan yang bersifat moderen. Pernyataan ini bukan tanpa alasan, melainkan dengan menganalisis berbagai konteks Pondok Pesantren Darul Qur'an Al Anwariyah Tulehu itu sendiri yang memadukan sistem pembelajaran pesantren dengan proses pendidikan sekolah formal di dalamnya, kemudian menggunakan dua bahasa yang diwajibkan dalam aktifitas sehari-hari di pondok pesantren, yakni bahasa Arab dan bahasa Inggris.

Pesantren merupakan asrama pelajar Islam dimana para santri belejar di sekolah-sekolah atau di perguruan-perguruan tinggi di luarnya. Pendidikan agama di pesantren model ini diberikan di luar jam-jam sekolah sehingga bisa diikuti oleh semua santrinya. Diperkirakan pesantren jenis inilah yang tebanyak jumlahnya (Kompri, 2018).

Pada dasarnya, seperti disajikan di atas, pondok pesantren terbagi kedalam tiga model. Sebagaimana (Bahri Ghozali, 2002) mengemukakan tipe pondok pesantren terbagi ke dalam tiga tipe, diantaranya;

a. Pondok Pesantren Tradisional yaitu pondok yang dalam perkembangannya pesantren tersebut menyelenggarakan pelajaran dengan pendekatan tradisional. Pembelajarannya ilmu-ilmu agama Islam dilakukan secara 
individual atau kelompok dengan konsentrasi dengan kitab-kitab klasik berbahasa Arab.

b. Pondok Pesantren Modern adalah pondok pesantren yang menyelenggarakan kegiatan pendidikan dengan pendekatan modern melalui suatu pendidikan formal, baik madrasah ataupun sekolah, tetapi dengan menggunakan cara klasikal.

c. Pondok Pesantren Komprehensif adalah pondok pesantren yang sistem pendidikan dan pengajarannya gabungan antara yang tradisional dan yang moderen. Artinya didalamnya ditetapkan pendidikan dan pengajarannya kitab kuning dengan metode sorogan, bandongan, wetonan, namun secara regular sistem persekolahan terus dikembangkan.

Senada dengan yang disampaikan oleh Bahri Gozali di atas. Ziemek sebagaimana dikutip (Mahfud Juanaedi, 2017) secara garis besar menegemukakan pesantren di Indonesia menurut beberapa pengamat dapat dklasifikasikan ke dalam beberapa tipe:

a. Pesantren jenis $A$, yaitu pesantren yang hanya terdiri dari unsur masjid dan rumah kiai.

b. Pesantren jenis $B$, yaitu pesantren yang memiliki masjid, rumah kiai dan pondok.

c. Pesantren jenis C, yaitu pesantren yang terdiri dari masjid, rumah kiai, asrama atau pondok dan madrasah.

d. Pesantren jenis D, yaitu pesantren yang sudah terdiri dari beberapa unsur yaitu masjid, rumah kiai, asrama, madrasah ditambah pendidikan keterampilan, program pertanian, dan lain-lain.

e. Pesantren jenis $E$, yaitu pesantren jenis modern, yang terdiri dari beberapa elemen yaitu masjid, rumah kiai, pondok, madrasah, dan universitas.

Dalam tahap perkembangannya, Zamakhsyari Dhofier dalam Kompri mengklasifikasikan pesantren ke dalam dua bagian:

c. Pesantren Salaf, adalah lembaga pesantren yang mempertahankan pengajaran kitab-kitab klasik sebagai inti pendidikan. adapun sistem madrasah ditetapkan hanya untuk memudahkan sistem yang dipakai dalam 
lembaga-lembaga pengajian bentuk lama, tanpa mengenalkan pengajaran pengetahuan umum.

d. Pesantren Khalaf, adalah lembaga pesantren yang memasukan pelajaran umum dalam kurikulum madrasah yang dikembangkan, atau pesantren yang menyelenggarakan tipe-tipe sekolah umum seperti SMP, SMA dan bahkan perguruan tinggi dalam lingkungannya (Kompri, 2018).

Adapun secara operasionalnya Pondok Pesantren Darul Qur'an Al Anwariyah Tulehu menerapkan model-model pondok pesantren yang dapat dikemukakan berikut;

a. Memadukan sistem pembelajaran pesantren dengan pembelajaran formal, sistem pembelajaran yang diterapkan pada pondok pesantren Darul Qur'an Al Anwariyah Tulehu menerapkan sistem pembelajaran umum dan juga proses pembelajaran pesantren. Hal ini dikarenakan pondok pesantren ini memiliki sistem pendidikan formal didalamnya terdiri dari Ula untuk setingkat SD/MI dan Wustho untuk setingkat SMP/MTs.

b. Pondok pensatren ini memfokuskan para santrinya untuk menjadi para santri penghafal Al-Qur'an. Mendukung proses ini, dimasukan kurikulum tahfidz (hafalan) bagi santri dalam proses pembelajaran di kelas, oleh karena itu di raport pendidikan santri ada termasuk nilai tahfidz di dalamnya.

c. Memakai dua bahasa yang diwajibkan dalam aktifitas sehari-hari di pondok pesantren, yakni bahasa Arab dan bahasa Inggris. Dalam pelaksanaan pendidikan keseharian Pondok pesantren Darul Qur'an Al Anwariyah Tulehu menerapkan proses komunikasi dengan menggunakan bahasa Arab dan bahasa Inggris dalam percakapan sehari-hari di pondok pesantren. Selain itu jadwal percakapannya di atur setiap dua minggu satu kali. Minggu pertama dan kedua di awal bulan memakai percakapan dengan bahasa Arab kemudian minggu ketiga dan keempat di pertangahan dan akhir bulan menggunakan bahasa Inggris, kadang juga di minggu pertama dan kedua menggunakan bahasa Inggris dan minggu ketiga dan keempat menggunakan bahasa Arab.

Dengan demikian dapat disimpulkan pondok pesantren Darul Qur'an Al Anwariyah Tulehu, dapat dikategorikan sebagai pondok pesantren dengan 
menerapkan sistem pendidikan yang bersifat moderen. Pernyataan ini bukan tanpa alasan, melainkan dengan menganalisis berbagai konteks Pondok Pesantren Darul Qur'an Al Anwariyah Tulehu itu sendiri yang memadukan sistem pembelajaran pesantren dengan proses pendidikan sekolah formal di dalamnya, kemudian menggunakan dua bahasa yang diwajibkan dalam aktifitas sehari-hari di pondok pesantren, yakni bahasa Arab dan bahasa Inggris.

\section{Tinjauan Santri di Pondok Pesantren Darul Qur'an Al Anwariyah Tulehu}

Salah satu unsur pokok dari pondok pesantren adalah santri. Secara umum santri dapat dikelompokan kedalam dua katgori yaitu santri mukim dan sntri kalong a) Santri mukim, adalah santri yang berasal dari daerah yang jauh dan menetap dalam pondok pesantren (Hasbullah, 1996). Santri mukim yang paling lama tinggal di pesantren tersebut biasanya merupakan satu kelompok tersendiri yang memegang tanggung jawab mengurusi kepentingan pesantren sehari-hari, mereka juga memikul tanggung jawab mengajar santri-santri muda tentang kitab-kitab dasar dan menengah (H.M Yacub, 1993). b) Santri kalong ialah santri-santri yang berasal dari daerah-daerah sekitar pesantren dan biasanya mereka tidak menetap dalam pesantren. Mereka pulang ke rumah masing-masing setiap selesai mengikuti suatu pelajaran di pesantren (Hasbullah, 1996). Yaitu murid-murid yang berasal dari daerah sekeliling pesantren, yang biasanya tidak menetap dalam pesatren. Untuk mengikuti pelajaran di pesantren, mereka bolak-balik (nglajo) dari rumahnya sendiri. Biasanya perbedaan antara pesantren besar dan pesantren kecil dapat dilihat dari komposisi santri kalong (Zamakhsyari Dhofir, 1985).

Pada dasarnya kategorisasi antara santri mukim dan santri kalong di setiap pondok pesantren adalah untuk membedakan antara santri yang menetap di asrama pondok pesantren dan santri yang tidak menetap di pondok pesantren atau yang tinggal di sekitar pondok pesantren. Di Pondok Pesantren Darul Qur'an Al Anwariyah Tulehu ketgori santri juga terbagi atas santri mukim dan santri kalong, yang termasuk dalam kategori santri mukim dimulai santri pada jenjang pendidikan kelas 4 SD sampai dengan lulus SMP. Sementara itu santri kalong dapat dikategorikan pada jenjang pendidikan kelas 1 sampai kelas 
3 SD. kelas 1 sampai 3 SD masih dibolehkan untuk pulang. Akan tetapi sebagian diantara mereka juga ada yang ingin menjadi santri mukim.

Santri adalah para pelajar yang tinggal di pondok pesantren. Atau juga dalam dunia pesantren istilah santri adalah murid pesantren yang biasanya tinggal di asrama atau pondok (H.M Yacub, 1993). Tinjauan tentang santri selain disebutkan di atas seperti santri mukim dan juga santri kalong, para ahli juga menambahkan, sebagaimana Arifin dan Sunyoto dalam Imron Arifin menemukan bentuk kelompok santri yang lain seperti.

a. Santri Alumnus

Adalah para santri yang sudah tidak dapat aktif dalm kegiatan rutin pesantren, tetapi mereka masih sering datang pada acara-acara tertentu yang diadakan pesantren. Mereka masih memiliki komitmen hubungan dengan pesantren, terutama terhadap kyai pesantren (Imron Arifin, 1993). Di pondok pesantren Darul Qur'an Al Anwariyah Tulehu peran santri Alumni bagi pondok pesantren sangat berarti. Sebagian para santri yang telah lulus dalam menempuh pendidikannya memiliki andil besar untuk kembali mengabdikan dirinya sebagai tenaga pengajar di pondok pesantren ini. Itu artinya secara tidak lansung para santri tersebut memiliki komitmen yang kuat terutama kepada pesantren, dan tuan gurunya (Observasi, 2019).

Keberadaan alumni bagi pondok pesantren Darul Qur'an Al Anwariyah sangat penting. Selain sebagai tenaga pengajar, keberadaan alumni memainkan peran penting dalam perkembangan pondok pesantren. Selain itu juga para santri Almuni yang diberdayakan oleh pondok pesantren, pada dasarnya memiliki komitmen yang kuat terutama kepada pesantren, dan tuan gurunya dalam rangka memajukan pondok pesantren tersebut ke arah lebih baik. Seperti harapan yang diuatarakan di atas terutama kepada para santri pondok pesantren Darul Qur'an Al Anwariyah.

b. Santri Luar

Menurut Arifin dan Suyoto dalam Imran Arifin bahwa santri luar adalah santri yang tidak terdaftar secara resmi di pesantren sebagaimana santri mukim dan santri kalong, tetapi mereka memiliki hubungan batin yang kuat dan dekat dengan kiyai, sewaktu-waktu mereka mengikuti pengajian-pengajian agama 
yang diberikan oleh kyai, dan memberikan sumbangan parsitipatif yang tinggi apabila pesantren membutuhkan sesuatu (Imron Arifin, 1993).

Di Pondok Pesantren Darul Qur'an Al Anwariyah Tulehu, selain adanya pendidikan pesantren di dalamnya, ada juga Taman Pengajian Al-Qur'an (TPQ) Nurul Latif. Para santri di TPQ Nurul Latif tidak terdaftar secara resmi di pondok pesantren melainkan hanya terdaftar pada TPQ. Adapun para santri di pondok pesantren juga mengikuti pembelajaran Al-Qur'an di TPQ juga. Selain itu jadwal pembelajaran di TPQ nya dilaksanakan setiap hari pada hari Senin sampai Sabtu pada waktu selesai sholat Ashar kemudian pada hari Minggu pada pagi hari jam 08.00 WIT. Para santri di TPQ juga mengikuti pengajian-pengajian agama yang diberikan oleh Tuan Guru atau Ustad.

Selain TPQ ada juga majelis pemuda (masyarakat tulehu yang tinggal di sekitar pondok pesantren) majelis ini bernama Nada Nan. Majelis ini pertama didirikan sekitar tahu 1990, pernyataan ini sesuai dengan yang disampaikan; majelisnya bernama Nada Nan (majelis pemuda). Adanya majelis dari sekitar tahun 90-an dan masih eksis sampai sekarang (Reza Aristo Briliansyah, ww, 2019).

Dengan demikian dapat dipahami, tinjauan tentang para santri di Pondok Pesantren Darul Qur'an Al Anwariyah, berdasarkan analisis yang dilakukan pada beberapa teori di atas, dapat dikategorikan santri pada Pondok Pesantren Darul Qur'an Al Anwariyah Tulehi meliputi Santri Mukim, Santri Kalong, Santri Alumnus dan Santri Luar.

1) Santri mukim adalah santri santri yang tempat tinggalnya berjauhan dengan lokasi pondok pesantren, tetapi ada juga sebagian santri yang tempat tinggal dekat dengan pondok pesantren memilih untuk menjadi santri mukim. Adapun dalam kategori santri mukim dimulai santri pada jenjang pendidikan kelas 4 SD sampai dengan lulus SMP. 2) Santri kalong adalah santri yang tempat tinggal mereka berada dekat di sekitar pondok pesantren, santri kalong dapat dikategorikan pada jenjang pendidikan kelas 1 sampai kelas 3 SD. kelas 1 sampai 3 SD masih dibolehkan untuk pulang ke rumah mereka. 3) Santri alumnus adalah santri yang telah lulus dalam kegiatan rutin di pondok pesantren. Sebagian para santri yang telah lulus dalam menempuh 
pendidikannya memiliki andil besar untuk kembali mengabdikan dirinya sebagai tenaga pengajar di pondok pesantrennya. 4) Santri Luar adalah santri yang secara resmi tidak terdaftar di pesantren seperti santri mukim dan santri kalong akan tetapi keberadaan mereka memiliki hubungan yang baik dengan pondok pesantren. Adapun yang termasuk santri luar di Pondok Pesantren Darul Qur'an Al Anwariyah Tulehu adalah para santri di TPQ Nurul Latif dan juga majelis pemuda (masyarakat tulehu yang tinggal di sekitar pondok pesantren).

\section{KESIMPULAN}

Dengan demikian dapat disimpulkan Pondok pesantren Darul Qur'an Al Anwariyah Tulehu merupakan model pondok pesantren Moderen dengan tipe yang diterapkan a) Memadukan sistem pembelajaran pesantren dengan pembelajaran formal, b) Pondok pensatren ini memfokuskan para santrinya untuk menjadi para santri penghafal Al-Qur'an, c) Memakai dua bahasa yang diwajibkan dalam aktifitas sehari-hari di pondok pesantren, yakni bahasa Arab dan bahasa Inggris.

Selain itu tinjauan tentang para santri di Pondok Pesantren Darul Qur'an Al Anwariyah, berdasarkan analisis yang dilakukan pada beberapa teori di atas, dapat dikategorikan santri pada Pondok Pesantren Darul Qur'an Al Anwariyah Tulehu meliputi Santri Mukim, Santri Kalong, Santri Alumnus dan Santri Luar.

\section{DAFTAR PUSTAKA}

[1] Arifin, Imron. (1993). Kepemimpinan Kyai Kasus Pondok Pesantren Tebu Ireng, Malang: Kalimasyahadah Press.

[2] Bahri Ghozali, M. (2002). Pesantren Berwawasan Lingkungan, Jakarta: Prasasti.

[3] Dhofir, Zamakhsyari. (1985). Tradisi Pesantren Setudi Tentang Pandangan Hidup Kyai, Jakarta: LP3ES.

[4] Hasbullah. (1996). Kapita Selekta Pendidikan Islam di Indonesia, Jakarta: Raja Grafindo Persada.

[5] Hasbullah. (2001). Sejarah Pendidikan Islam di Indonesia, Jakarta: RajaGrafindo Persada, 2001.

[6] Junaedi, Mahfud. (2017). Paradigma Baru Filsafat Pendidikan Islam, Jakarta: Kencana. 
[7] Kompri. (2018). Manajemen Dan Kepemimpinan Pondok Pesantren, Jakarta: Prenadamedia.

[8] Mai Dhuhani, Elfridawati. (2018). Manajemen Pondok Pesantren : Studi Pengelolaan Santri Muallaf Di Pondok Pesantren Al Anshor Ambon, Yogyakarta: Deepublish.

[9] Mas'ud, dkk. (2018). dalam Kompri, jakarta: Prenadamedia Group.

[10] Nur Hasan, M. (2016). “Model Pembelajaran Berbasis Pondok Pesantren Dalam Membentuk Karakter Siswa (Penelitian pada Santri di Ponpes Raudhotut Tholibin Rembang )," TRANSFORMASI, Volume 12 Nomor 1.

[11] Observasi. (2019). pada pkl. 13.00 - 16.00, 29 Juli.

[12] Peraturan Pemerintah Republik Indonesia Nomor 55 Tahun 2007 Tentang Pendidikan Agama Dan Pendidikan Keagamaan.

[13] Ustad Reza Aristo Briliansyah. (2019). Wawancara pada tanggal 19 Pkl. 13.00 - 16.00 WIT Pondok Pesantren Darul Qur'an Al Anwariyah Tulehu.

[14] Wekke, Ismail Suardi. (2017). "Integrasi Pendidikan Islam dan Pembelajaran Kewirausahaan di Pesantren Minoritas Muslim," Fenomena, Volume 9 Nomor 1.

[15] Yacub, H.M. (1993) Pondok Pesantren dan Pembangunan Masyarakat Desa, Bandung: Angkasa. 